\title{
Entrevista: \\ Minúcias do espaço de afeto envolvido na manifestação pictórica de um universo paralelo
}

\author{
Cristiane Weber ${ }^{1}$ \\ Alejandro Pasquale ${ }^{2}$
}

Na tese defendida em fevereiro de 2019 no Programa de Pós-graduação em Processos e Manifestações Culturais da Universidade Feevale, orientada pelo Prof. Dr. Daniel Conte e co-orientada pelo Prof. Dr. Ernani Mügge, apresentei como corpus a obra de Alejandro Pasquale (figura 1). $\mathrm{O}$ artista é destaque entre os pintores contemporâneos argentinos e, antes de apresentar a entrevista que trago a esta edição, peço licença para trazer mais alguns detalhes sobre o contexto no qual a pesquisa se desenvolveu.

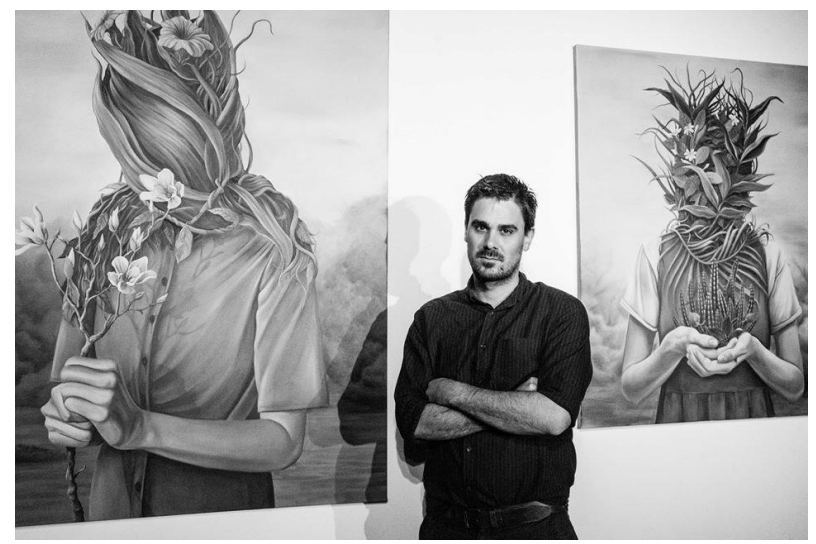

Figura 1 - Alejandro Pasquale durante exposição de sua obra

Alejandro nasceu em 16 de março de 1984 no bairro de Nuñez, em Buenos Aires, uma pacata vizinhança com menos de quatro quilômetros quadrados. Ale, como gosta de ser chamado, recebeu inúmeros prêmios e reconhecimentos, como o prêmio Fundação Cultural Itaú na Argentina (2013 e 2016), $1^{\circ}$ lugar no Salão de Arte Contemporânea do MACA (Museu de Arte Contemporânea Argentino), em 2015, e destaque na Bienal Nacional de Pintura de Rafaela (AR), entre outros.

Conheci o trabalho do artista durante um jantar na casa de um médico argentino em 2016. Na sala da casa do anfitrião, quadros repousavam nas paredes e outros estavam apenas escorados, com pequenas luminárias que individualizam as telas. Uma das pinturas me chamou a atenção: acima da lareira, uma tela de cerca de 1,5 metros de altura, descansava incólume um quadro, óleo sobre tela, ilustrado com o que aparentava ser um menino, segurando dois pássaros em um ramo, com uma enigmática máscara no rosto. "Que queres,

1 Doutora em Processos e Manifestações Culturais pela Universidade Feevale. Professora do curso de Jornalismo da Universidade Feevale.

2 Artista plástico argentino. Cursou parcialmente Belas Artes. 
menino?", pergunto intimamente ao me deparar com o quadro. A resposta foi devolvida com o mesmo olhar. “¿Qué querés vos, conmigo, afinal?”, disse ele em minha imaginação. Silêncio de minha parte também. E, de novo, a contemplação da tela (figura 2).

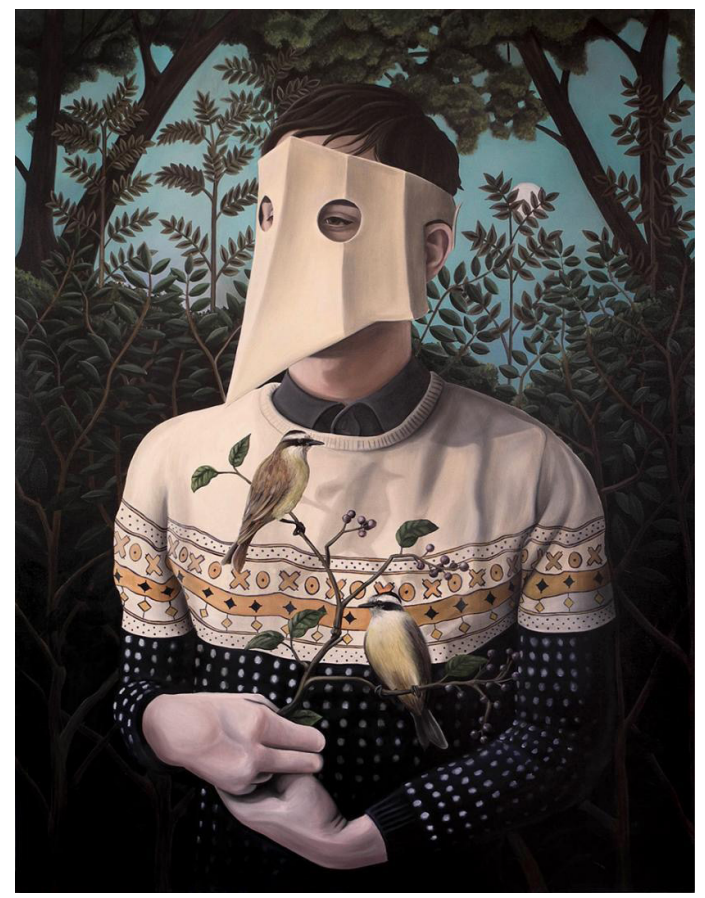

Figura 2 - Tela Equilibrio, por Alejandro Pasquale

Nos segundos seguintes, absorta naquela imagem tão instigante, coloquei-me no exercício da subjetividade: quem era o menino? Eu não sabia. Só senti o conforto daquele espaço que abrigava, agora, duas imagens que conversavam atônitas uma e outra: a criança mascarada e eu, mergulhada em mim. A presença dele deveria significar algo ao dono da casa. Aperto os olhos para tentar me livrar das sombras de uma das lâmpadas. O olhar continua distante e enigmático, contrário ao de uma foto onde a figura faz uma pose. Em um primeiro momento, fui assolada pela solidão daquela criatura. Incomodaram-me os pequenos buracos que possibilitam aquele olhar, em uma máscara que pode ter sido tolhida em madeira. Silêncio. Entro em suspensão subjetiva.

Continuei a fitar aquela figura e me senti angustiada. Se existiam orifícios para os olhos, a boca parecia presa e condenada a não se narrar, nem mesmo em sua agonia. Há de falar o menino, mas somente para si mesmo, pensei. Encarei a figura esperando que me dissesse algo. Que me repreendesse pela observação invasora, pela ocupação daquele espaço de estabilidade. Imaginei agora seus pensamentos trancafiados, com ressonância muito baixa, ecoando por debaixo da madeira que simulava um silêncio imposto. Seu blusão pesado, porém, alinhado, lembrou-me o de uma criança pronta para uma festa em família. Estranhei o galho que portava dois bem-te-vis, em posição contrária e, estranhamente, quietos e tranquilos nas mãos de uma criança. 
Minha imaginação foi subitamente interrompida pelo dono da casa. Perguntou-me sobre o quadro, se eu sabia sobre seu significado. Aquela sensação foi dúbia: até então, era apenas o desconhecido a formular teorias na minha mente. Porém, havia a curiosidade. A descoberta iminente. Afirmei ter gostado muito da obra, ao que o médico me explicou o contexto de criação: ao perder um sobrinho afogado em uma piscina, Alejandro Pasquale pintou $\mathrm{D}^{* 3}, \mathrm{o}$ menino (que tem um irmão gêmeo, $\mathrm{M}^{*}$ ) em crianças mascaradas, uma pincelada de existência, uma maneira de lhe manter vivo. Assim, a criança crescia (no sentido do passar dos anos) em suas obras, disse-me ele, porém sempre sem rosto, já que sua face de criança mais velha, Alejandro desconhecia. $\mathrm{D}^{*}$ morreu com apenas um ano de idade.

Alejandro teve sua vida e seu trabalho modificados pela tragédia familiar. A partir desse fato, as ilustrações do artista, geralmente em caneta sobre papel e com uma perspectiva de olhar externo, observando seus modelos, transformaram-se em grandes quadros de óleo sobre tela, onde um realismo mágico colore não só os primeiros trabalhos após a perda, como também a obra que se estende até hoje e provoca um olhar mais introspectivo.

Há uma linha bem marcada nesse processo, entre dezembro de 2013 (data do ocorrido) e abril de 2014. No repositório Bola de Nieve 4 , espaço para divulgar portfolio de artistas argentinos, Alejandro possui um perfil desde 2012. Ao acessar a página, há uma mudança nas características de seu trabalho justamente o período marcado pela perda do sobrinho. Na tela Polaroid, datada de 2013, por exemplo, a técnica utilizada é a de caneta sobre papel. Aparece um menino com cabelos loiros acessando um escorregador, em um local que se parece com um parque. Após dois quadros semelhantes, sempre com a mesma técnica, surge o primeiro menino mascarado da nova série, na tela Un Otoño $L u z$, de 2014, na técnica lápis sobre papel. Nela, uma criança de cabelos castanhos tem o rosto escondido por uma máscara, em meio a um bosque fechado. É possível comparar as diferenças, se colocarmos lado a lado um dos últimos trabalhos desse "antigo" estilo e um do novo, marcado pela série "Universo Paralelo" (figura 3).

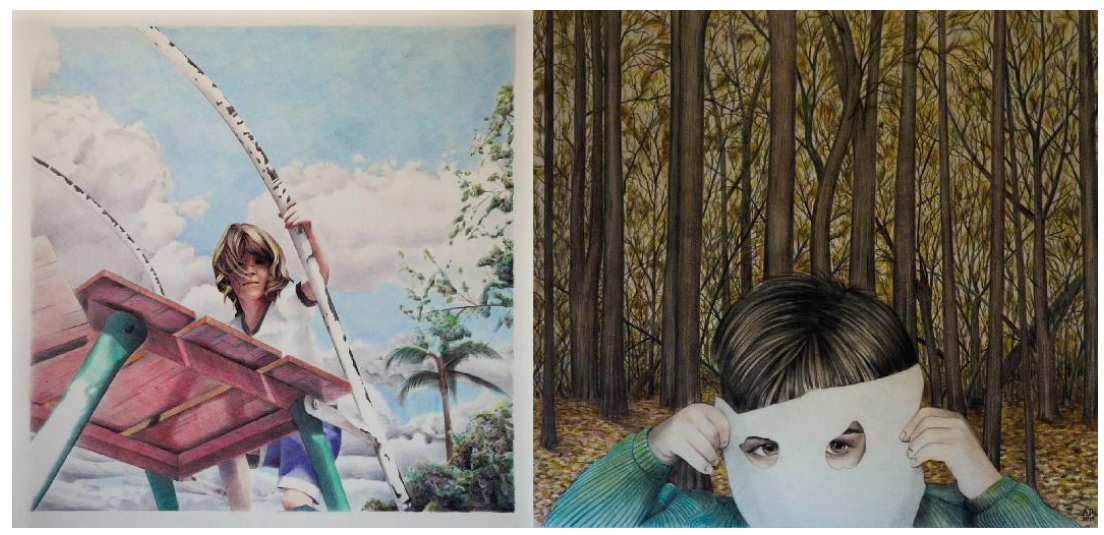

Figura 3 - Montagem com as telas Polaroid e Un Otoño Luz, por Alejandro Pasquale

3 Nota minha: os nomes da criança e do irmão gêmeo foram preservados dentro dos princípios éticos e do respeito à família do pintor.

4 O site Bola de Nieve abriga a obra atualizada do artista, incluindo dimensões. Disponível em $<$ http://www. boladenieve.org.ar/node/19076>. Acesso em: 14 jan. 2019 
A primeira tela, Polaroid, foi postada em 2013 no perfil no Facebook do artista. Em técnica caneta sobre papel, tamanho $65 \times 65 \mathrm{~cm}$, a pintura está ambientada em um dia com sol entre nuvens, em um parque infantil. As cores do desenho são vibrantes, com bom contraste. Ao redor do parque - ou até mesmo na área do playground - há árvores de copas altas: um coqueiro e outra espécie de folhas pequenas e médias. Em primeiro plano está um brinquedo que se assemelha a um escorregador, com hastes de acesso brancas enferrujadas e um apoio em tábuas na cor vermelha. Há um pedaço de madeira que reforça a ideia do escorregador, em um ângulo de aproximadamente $45^{\circ}$, que sinaliza a rampa de descida. A sustentação do brinquedo se dá com hastes de ferro pintadas na cor verde. A perspectiva de olhar do artista é da base do brinquedo para cima, próximo a este pedaço de madeira por onde o menino irá descer. A criança devolve a atenção para o artista e faz um movimento de subida em direção ao ápice da brincadeira. Seus cabelos compridos e longos lhe cobrem os olhos. O pequeno aparenta três anos de idade (não é possível identificar seu gênero), vestindo uma bermuda azul de barras brancas e uma camiseta branca em gola "V" com abas marrons. A padronagem lembra a de um uniforme escolar. Por isso, acredito que possa estar em um parque da cidade antes ou após a aula ou até mesmo no pátio da escola.

Subindo apressado no escorregador, há tempo para uma parada do olhar de uma criança. Esse olhar é eterno, terno, e leva consigo um sorriso tímido. O menino ou a menina do retrato é só curiosidade. Seu tempo já está congelado (para as crianças, todo o tempo do mundo). Na próxima passada, à plataforma, a criança estará frente ao desafio e à liberdade. O pedaço de tábua de resguardo, em madeira que lembra o tom do carvalho, é o portal do vento aos cabelos. A descida durará um segundo, se tanto. É na antecipação do momento, portanto, que mora a ansiedade e a felicidade. É a parada ao olhar do artista que denuncia que aquele instante não precisa acabar no segundo que separa a plataforma do chão. Recém-saído da escola, ele ou ela está de uniforme. Não há tempo para chegar em casa, trocar a roupa. Melhor ir direto, sem interrupções, sem chance para qualquer mudança de planos. Um joelho se apoia na escada. O outro, antecipa a chegada.

Os cabelos grudados ao rosto entregam que a brincadeira já havia iniciado há algum tempo. A praça é lugar de brincar e de imaginar há muitos anos: há um corroído corrimão por onde outras muitas pequenas mãos já passaram. O tempo desgasta o metal, mas não as histórias que por ali se apegaram. Ao fundo, árvores de copas altas, incluindo um coqueiro que se destaca, integram a paisagem como coadjuvantes. É ao centro que se desenrola a cena que Alejandro observa de baixo, possivelmente sentado na areia. Nuvens brancas e densas se desenham, mas, de momento, é impossível saber se o tempo mudará. Um sol alto, vindo na perspectiva da frente da criança, indica que esteve pela escola no período da manhã. É um dia claro e normal, onde tudo o que acontece também faz parte de uma rotina. É quase possível ouvir, ao fundo, os sons do lugar: risadas agudas, passos abafados na areia, o tilintar dos pedregulhos, os farelos de pães e bolos caindo suaves, a roda dos carrinhos, as conversas entre pais, mães e conhecidos. Uma praça é um depósito de metais encaixados se não houver uma ou dezenas de crianças. É preciso haver vida. E há muita vida nesse registro do tempo.

$\mathrm{Na}$ técnica de Alejandro, muitas cores, ainda que suaves. O detalhamento que o seguirá por toda a jornada como artista é presente: da ferrugem no corrimão aos detalhes de realismo em tudo, principalmente na criança, há um cuidado especial às pequenas nuances da imagem. Até as ranhuras que dão base à madeira da tábua de impulso estão 
retratadas, assim como a sombra que atravessa os vãos da estrutura. Um desenho de pura observação, onde mais uma vez se encontra uma cena do cotidiano, congelada no tempo e na memória do artista.

Na poética de Gaston Bachelard, encontro alguns significados importantes: para o autor (1971, p. 86), significa que uma infância potencial está em nós "quando a reencontramos em nossos devaneios, mais ainda que em sua realidade, nós a revivemos em suas possibilidades. Sonhamos tudo o que ela poderia ter sido, sonhamos no limite da história e da lenda". Símbolos de um retrato da vida capturada naquele breve instante de tempo, onde a criança sobe pelo escorregador para sentir o vento, o calor do sol, o sabor da vida que só esse período da infância proporciona com tal intensidade. Quando chega ao chão, afoito pela descida rápida, faz girar o corpo à mesma base que lhe levará à mesma sensação. Inúmeras e inúmeras outras vezes.

O segundo quadro marca o primeiro processo transitório de estilo: trata-se de $U n$ Otoño Luz, de 2014, publicada na página do Facebook em 26 de abril do mesmo ano. Uma pintura feita em técnica lápis sobre papel, em 2014, com dimensões de 51 x $57 \mathrm{~cm}$. Surge com uma criança (também de gênero indefinido), em primeiro plano, segurando uma máscara que aparenta ser feita de papel em frente ao rosto. A máscara tem dois orifícios pequenos através dos quais podem ser vistos os olhos, de cor escura, e um pedaço pequeno das sobrancelhas. No solo, há uma camada espessa de folhas que caracterizam o outono, em coloração marrom-clara, demarcando a estação. Há uma mata densa atrás da criança, com muitas árvores, todas com tronco fino e comprido e galhos que alternam folhas mais verdes e outras mais secas. Há alguns galhos entrecruzados próximos ao solo, indicando desgaste, queda ou crescimento irregular. A projeção da floresta é infinita.

$\mathrm{Na}$ tela, uma pergunta: é possível se esconder da realidade? Ainda mais com um pedaço de papel? O menino da imagem é pequeno, tem seus poucos três ou quatro anos. Não está aos pés do escorregador, nem ao lado do animal de estimação. Encontra-se parado, estático, os cabelos aprumados e bem penteados. Não tem o suor das brincadeiras do verão argentino. A roupa agora não é o leve uniforme escolar: aparece um blusão grosso, de lã penteada, em cores desbotadas. Nas mãos, o menino segura uma máscara mal recortada (com bordas irregulares), que parece ser feita em papel. Há dois pequenos orifícios por onde se enxergam os olhos da criança, um pouco desconfiados do que acontece ao redor. $\mathrm{O}$ pequeno tem uma pele em cor fria, quase gélida, com as pontas dos dedos levemente destoantes. Ao fundo, nada de brinquedos da antiga praça: um bosque fechado se ergue de forma opressora. Há inúmeras folhas e galhos, que descansam solenes sobre um infinito de resquícios outonais da natureza. Alguns sobrevivem presos às árvores, em tons de verde engolidos pelo amarelo do pré-descarte. Em troncos finos, os pinheiros se levantam e se acumulam, formando um infinito caminho, o que revela uma paisagem densa. Poucos galhos ou árvores ainda muito finas se esgueiram, apoiando-se nas mais fortes: não sobreviveram, ainda jovens, ao tempo ou à falta de luz do local. Da alegria ao enigma. Em Bachelard, um tanto a mais de significados: a árvore, aqui, tem outra conotação, diferente da anterior. Trata-se de uma devolução ao cosmos motivada pela morte, em uma das tantas concepções da árvore formuladas pelo autor:

Ao nascer, o homem era consagrado ao vegetal, tinha sua árvore pessoal. Era preciso que a morte gozasse da mesma proteção que a vida. Assim recolocado no coração do vegetal, devolvido ao seio vegetante da árvore, o cadáver era entregue ao fogo ou à terra; ou então 
ficava esperando na folhagem, no cimo das florestas, a dissolução no ar, dissolução ajudada pelos pássaros da Noite, pelos mil fantasmas do Vento. Ou, enfim, mais intimamente, sempre estendido em seu esquife natural, em seu duplo vegetal, em seu sarcófago vivo e devorador, na Árvore - entre dois nós -, ele era entregue à água, abandonado às ondas. (Bachelard, 1971, p. 247)

O bosque representa um conjunto de árvores que dividem a dor do artista. Choram com ele, naquele assovio característico, a mudança de uma realidade outrora feliz. Servem de esquife à existência em matéria do sobrinho, que já não é mais uma realidade. Un otoño luz, enquanto pintura, é precursora de um novo estilo na vida de Alejandro. Difere-se de muitas outras que ele colecionava e compartilhava nas redes. De uma observação apurada sobre o cotidiano alheio, em cenas rotineiras, o artista argentino passa a pintar o imaginado.

Com uma vasta obra que se estende pela imaginação e pelo sonho e rodeado por memórias do sobrinho e da própria existência, Alejandro coloca em seu trabalho um diário aberto. Dele, abre páginas através de imagens que trazem elementos construídos para sensibilizar. Tudo isso através de um processo criativo marcado por características singulares, próprias a uma perspectiva transcendente e de vínculos afetivos. Ainda vasculhando seus acervos, percebo um ponto interessante na evolução da jornada como artista: antes da morte da criança, Alejandro possuía uma técnica específica de trabalho e de materialidades, marcados pela observação do cotidiano. O fato trágico, porém, transforma esse processo, alterando não só a técnica, mas os significantes e significados expostos nesse novo momento. A obra, assim, responde à transição desse processo evolutivo, associado a um olhar interno mais atento e mais apurado. O resultado disso são imagens poéticas de múltiplos atravessamentos, de inúmeras vivências e de afetos, principalmente.

A contextualização acima se fez necessária para embasar a entrevista a seguir. A pesquisa que teve como resultado a tese abordou duas telas anteriores a Polaroid e algumas outras posteriores a Un Otoño Luz, para compreender as mudanças decorrentes de um processo de cura, ligado à morte da criança e, também, de amadurecimento profissional do artista. A análise teve filiação fenomenológica, principalmente através da fenomenologia microscópica de Bachelard (1993). Abarcando teorias relacionadas à arte contemporânea em autores como Rancière (2009), das bases neurais da criatividade em Abraham (2016), do processo de criação em Csikszentmihalyi (2008), da evocação de memórias em Izquierdo (2002) e Halbwachs (2003), além dos espaços poéticos de Bachelard (1993), entre outros, o estudo buscou avançar na compreensão de como o processo criativo pode servir de catarse e ser fundamental no processo de cura em uma situação de luto vivida por um artista.

Em março de 2018, ainda, viajei a Buenos Aires (AR) para compreender mais sobre a vida e a prática artística de Alejandro, não só para trazer ao trabalho uma análise pautada pela perspectiva poética, mas também para inserir um capítulo voltado à crítica genética em minha tese. De acordo com Cecília Salles (2008), o método é coerente quando quer buscar no pintar, no explorar e no imaginar do artista a primeira conexão estabelecida. Pois é esse ato fascinante, que não nasce do dia para a noite, que promove o encontro mágico com a arte. É no trabalho de Alejandro que se encontra o primeiro laço. Com o claro intuito de analisar os rastros deixados pelo artista, a crítica genética passou a ser um modelo interessante de análise à medida que serviu de método para analisar tudo o que encontrei em minha viagem, quando registrei fotos e vídeos de objetos de decoração, objetos da infância, telas em execução, instrumentos de trabalho e outros detalhes do atelier. 
De acordo com Salles (2008, p. 25), diante dessa perspectiva, ligada ao desenvolvimento e execução criativa, "a obra não é, mas vai se tornando, ao longo de um processo que envolve uma rede complexa de acontecimentos".

Trouxe, ao longo da pesquisa, aspectos sobre como o artista expõe e pinta suas memórias e assim se conecta às memórias de quem observa. Mais que isso, como a própria obra se forma através de suas lembranças, anotações, passos que se seguem até o caminho final. São camadas e mais camadas de pensamentos, reveladas por esses rastros. Tratou-se, assim, de uma análise que teve a intenção de conhecer a obra não especificamente em seu produto materializado, mas nas suas minúcias e versos, desde as primeiras pinceladas.

Uma vez apresentados detalhes da pesquisa, trago, a seguir, a entrevista realizada no atelier do artista, também parte do dossiê elaborado pelo método da crítica genética.

\section{Diga-me seu nome, sua profissão e sua cidade.}

AP - Me chamo Alejandro Pasquale, sou artista visual e moro em Buenos Aires, Argentina.

\section{Quando você começou a pintar?}

AP - Na realidade, desde pequeno sempre gostei de pintar, com diversos materiais. Mas a pintura, por si mesma, foi por volta dos 14 anos, como uma saída ou refúgio do que estava vivendo naquele momento. Logo depois de uns anos me reconectei com as artes plásticas e aos 26 anos encarei isso como uma profissão. Antes, quando era "amador", era mesmo um refúgio, sem um fim especial, algo que precisava para o momento para sobreviver.

\section{E o que você gostava de pintar naquela época?}

AP - Gostava de pintar alguns personagens. Eu não tinha tela para pintar, o que eu encontrava, pintava. Bolsas, madeiras. Mas era muito efêmero, eu pintava e depois descartava. Não buscava que isso transcenderia com o tempo, buscava me extraísse do tempo que eu vivia. Isso era importante e tinha uma função fantástica.

\section{Especificamente sobre a obra com máscaras, como ela começou na sua vida como artista?}

AP - É como uma espécie de linguagem onde está a metáfora de libertação do imaginário, de uma consciência paralela, que não poderia ser concebida em um universo social. A máscara aparece como isso. A composição do quadro aparece como um universo paralelo que os personagens estão vivendo naquele momento. A máscara é como uma chave, uma porta. É como o frasquinho de Alice no País das Maravilhas ${ }^{5}$, um frasquinho que se bebe e que se aparece em um mundo paralelo, essa é a máscara para um personagem retratado. Quando comecei a pintar as peças estava em um lugar confortável, onde me sentia cômodo. Eu me sentia autêntico com o que estava falando, estava expressando. Sempre fui autêntico e penso que muitas vezes estive influenciado por questões externas, aí me dei conta que comecei a trabalhar com algo muito forte. Não sei se pintarei essas máscaras para sempre, mas foi muito forte. É um ponto de vista a respeito do mundo.

5 Nota minha: "As Aventuras de Alice no País das Maravilhas", conhecida popularmente como Alice no País das Maravilhas (Alice in Wonderland) é a obra infantil mais conhecida de Charles Lutwidge Dodgson, publicada em 4 de julho de 1865. O frasco mencionado por Alejandro se refere a uma poção ingerida pela menina, que a faz encolher e se aventurar pela terra das maravilhas. 


\section{Como você considera que acontece o processo criativo da série?}

$\mathrm{AP}$ - Na verdade, não se trata de uma série, eu penso. É um paralelismo a respeito da minha vida, aos meus interesses, uma maneira de me encontrar no mundo. É como tentar definir a vida em séries, que são mais que nada épocas. Esse momento começa todo através de uma sensação, de uma ideia, de uma ambição. Bom, muitas vezes aparece através de plantas sagradas que consumo ou em cerimônias. Nesse momento eu entro muito dentro de mim e sou capaz de ver coisas que talvez no dia a dia nãos seja tão fácil chegar a este estado de sensibilidade, a este estado emocional tão pouco acessado, invadido com a postura geral da sociedade ante o mundo, ante as redes sociais, ante o trabalho. Encontro este estado e vejo o que ele representa e faço uma imagem. A partir disso, dessa necessidade, é que surge todo o resto. Depois vem o processo criativo da obra em si mesma, com um desenho que pode ser muito simples em lápis, que vou enxertando com imagens. Imagens feitas por mim, encontradas na Internet, em livros de botânica, em lugares distintos. O que importa é a imagem final, não importa se em pedaços, de onde vêm, se é a máscara. $\mathrm{O}$ que importa é que a imagem final represente algo a mais, que represente a sensação dessa consciência paralela. A partir disso uso essa composição como guia para a obra final. Não será uma cópia também, não quer dizer que aquilo que esboço seja o final, nem nada. É simplesmente uma ideia. Depois vou transformando, digerindo esse desenho, esse esboço, e todo o processo significa mais ou menos um mês, um mês e meio de trabalho, e aí se tem uma torção disso tudo, com o que estará concluído na tela.

\section{E sobre as plantas sagradas? O que elas significam no seu processo criativo?}

AP - Tomo as plantas sagradas porque acredito que a natureza é uma ferramenta fantástica. Eu não sou ateísta ou sigo qualquer religião, mas creio que o budismo seja uma doutrina de vida que mais se aproxima ao que eu sinto. Há muitos artistas que trabalham durante toda a sua vida para chegar a um estado de consciência, na qual eu chego não como fazem os monges, mas através destas ferramentas que são as plantas sagradas. Por que as tomo? Porque além de ser essa ferramenta fantástica, é essa maneira de eu conhecer a mim mesmo, não o que a sociedade quer de mim, mas o que eu mesmo me exigi para criar. É uma essência pura do que fui eu, ao nascer, para onde vou, e nesse ponto existe um trânsito, estou passando por esse mundo neste momento. Depois eu não sei o que vai acontecer. Não sei, não tenho uma noção clara do que chamamos de morte. O que sei é que nesse momento as plantas sagradas fazem com que eu me conheça muito mais, o que eu sou como essência. Não o que eu sou para a sociedade, o que sou nas redes sociais, diante da minha mãe, meu pai, meu sobrinho. Obviamente estou neste plano carnal, e a melhor forma de desabrochar isso que aprendi nessa "viagem", a melhor forma é representar nessa pintura, é o melhor a se fazer. Há pessoas que fazem uso de substâncias para ir a uma festa e dançar, mas isso me parece um desperdício desse presente que é a natureza. A ayahuasca talvez tenha esse processo humano de manufatura, mas esse processo de cultivo, sabe, e tomar o que vem da terra, e que traz essa informação das primeiras coisas que estiveram aqui na Terra há milhões de anos, e que trazem essa genética, uma genética com toda essa informação, e são seres que se espalham pela Terra em quilômetros e depois saem, isso me parece que é muito incrível. Eu sempre gostei das plantas, e obviamente como seres a parte dos seres humanos e pensar nisso, que podemos nos mimetizar em uma única consciência, que se transforma em uma linguagem. Não uma linguagem, mas sensações, são movimentos energéticos. É uma ferramenta muito valiosa, a planta 
sagrada. E é preciso uma capacidade para se entregar a isso, a esse sentimento. Isso porque às vezes é uma sensação muito forte, como perder a corporalidade, por exemplo. Não para ter uma viagenzinha rica, o que me parece super válido também, compartilhar com amor, valorizar o que essas plantas te mostram, o que é mágico. Valorizar isso é muito bom. Entre você e eu não há somente ar, há moléculas, há energia, há sol, há um monte de coisas, sabe? E tudo isso as plantas sagradas podem te mostrar. Mas antes de um Alejandro Pasquale como artista há um Alejandro Pasquale que vive nesse mundo, que ama este mundo e valoriza muitas coisas deste mundo: o som dos passarinhos, o som das horas na Igreja. Desde pequeno sempre me encantaram as flores nascendo na primavera se depois secando. Então posso dizer, as plantas sagradas não são para todos. Mas não é uma droga, não é cocaína, não é químico. Meus quadros são processos de um estado de consciência. Uma droga você não cultiva com amor em sua casa, então isso não é uma droga. É um processo de vida, um processo da planta, um conhecimento próprio, um conhecimento do trabalho. Há pessoas que não conseguem sentir isso, então não chegam perto dessas plantas, porque sabem que a farão mal. Mas se você toma não pode lutar contra esse efeito, porque se você ingere algo e obviamente terá um efeito. E o melhor que pode fazer é enfrentar isso, acompanhar esse efeito e, já que está tendo acesso a essa ferramenta de acessar a sua consciência, que demonstre o que tem a mostrar. E se você se deparar com algo que lhe incomode demais, que saia para um lugar mais luminoso. Há pessoas que creem no Espírito Santo, e eu acredito no espírito da natureza.

\section{Algumas produções trazem pássaros, outros trazem passagens da sua infância na Patagônia... ao colocar isso nas suas artes, que papel têm as memórias e as suas pró- prias experiências vividas? De onde você busca isso?}

AP - Sabe quando você está fazendo uma imitação de um artista que você viu em um .tmblr ou um desenhador gráfico que trabalha para as necessidades de uma pessoa? Se você está trabalhando com algo interno você está em tudo. É raro que um artista não coloque em sua própria obra sua vida. Pode estar nas montanhas por onde vivi, na natureza daqui de Buenos Aires, nas plantas que consumo para ter estes estados de consciência alterados ou paralelos. Está em tudo. Talvez não na fisionomia das personagens. Não sou só eu representado: talvez uma mulher, ou porque sou um "eu feminino", é um monte de coisas que surgem assim. Claramente eu vivi nas montanhas e em lugares cercados pela natureza, e eu busco isso constantemente. Minha casa está cercada de natureza, de plantas. Meus mundos mental e físico são assim. E sobre isso, algumas pessoas chamam uma imagem minha de obra, e outros chamam de quadro. Eu creio que obra é algo mais estático, que vai crescendo ao longo do tempo e cada peça se transforma em uma parte dessa obra. Cada pintura é uma peça dessa obra. Na vida de uma pessoa que não pinta, sua vida é sua obra. Obra é um conceito, e as peças são materialidades. A obra é uma construção constante.

\section{Existe uma narrativa que conecta os seus quadros? Ou são momentos avulsos?}

AP - As pinturas são momentos, sentimentos ou passagens da minha vida. São vividos ou estão na minha consciência. Estou (estamos) como passageiros nessa nave, nesse mundo, nessa vida. Isso já é um fio conector entre minhas peças. E quando estão reunidas na mesma obra, são a minha vida, claramente. É só perceber os meus primeiros trabalhos, os interesses que eu tinha naquele momento, em que momento da vida eu estava, inclusive 
em relação à minha maturidade. E agora, em que momento da minha maturidade estou nesse momento, pessoal, emocional, profissional. Minha técnica vai crescendo - ou decrescendo - no caso. Sabe quando há um jogo entre bebês, quando põem as máscaras, e brincam que são algo? Eu brincava disso com meus primos na mata, éramos selvagens. E isso é parte de um jogo. É um universo paralelo que vai se gerando.

\section{Você disse que se inspira em um livro que ganhou quando criança para os formatos das máscaras que são colocadas nas imagens. Fale um pouco sobre isso.}

AP - A primeira máscara aparece em Un Otoño Luz que não vem a partir desse livro. Depois vieram as inspirações nesse livro. A máscara é isso, a liberação do imaginário, é a representação das plantas sagradas. Esse livro ganhei quando fiz aniversário de seis ou sete anos, não lembro muito bem. Uma amiga da minha tia veio e tinha feito máscaras para mim e para meus amigos que estavam convidados para essa festa de aniversário. Muitos anos depois, já fazendo os meus trabalhos de pinturas, aparece esse livro na minha vida. $\mathrm{O}$ mesmo livro que essa mulher havia usado para fazer essas máscaras, uns 20 anos atrás, ou mais, 30 anos atrás. Achei fantástico. Obviamente me serviu enquanto imagens, enquanto realização de um conceito mais forte, de uma narrativa muito mais forte. E sabe, eu tenho uma recordação muito forte desse aniversário, está vívido na minha memória. A máscara é mesmo um monte de coisas. E ela está associada a passagens, rituais, liberações, no contato com outros mundos. Nas tribos ancestrais as máscaras tinham uma representação muito forte. Na nossa vida, nós temos uma consciência mais pura e vamos fazendo um mascaramento: nossas máscaras no trabalho, nossas máscaras como pais, como parceiros. Não quer dizer que seja uma hipocrisia essa máscara. A máscara as vezes tem essa conotação de mentira, mas não é uma mentira. Há também as máscaras associadas à mentira, claro, mas outras máscaras podem não ser uma mentira. Mas ela pode encerrar o inconsciente. E as máscaras podem ser nossas vestimentas, nossos posicionamentos. Obviamente que você não irá se comportar da mesma forma com seu parceiro e com seu companheiro de trabalho. Estamos vivendo em uma sociedade. O importante é saber que temos um estoque de máscaras distintas e devemos usá-las corretamente. É preciso só saber em que momento usar cada máscara, cada linguagem, ou mesmo cada planta. Saber usá-la.

\section{E sobre o seu sobrinho, D*. Que papel tem ele nesse processo criativo e curativo da pintura? Como ele aparece?}

AP - Foi muito especial a relação que tive com ele. Não esperava em ter uma relação assim com um sobrinho. O último dia que vi ele foi em seu aniversário de um ano. Ele se apegou a mim e não me largou, não foi com outra pessoa. Nos botamos a caminhar, fazia apenas uma semana que ele estava caminhando. Fomos caminhar no campo, vimos o entardecer e empinamos uma pipa. Fizemos tudo. Vivemos toda uma vida nesta tarde. Lembro-me que voltei desse aniversário ainda mais apaixonado por ele, falava com todos os meus amigos sobre ele no WhatsApp. Foi fantástico e uma parte da minha vida e vai fazer parte das minhas recordações durante toda a minha vida. Eu já estava trabalhando em minhas peças, era um processo da minha obra plástica. Ele aparece muito na pintura Equilibrio, sou eu com eles ( $\mathrm{D}^{*}$ e o irmão $\mathrm{M}^{*}$, gêmeos bivitelinos). Essa pintura representa que estou segurando ambos com firmeza, mas com certa dor, e eu sei que eles voam. Pássaros voam. Podem pousar no galho, podem voar. E a verdade é que $\mathrm{D}^{*}$ se foi deste 
mundo muito cedo. De certa forma eu representei a lua, as estrelas, sempre fui muito ligado a isso. A lua tem a ver com o céu. Estive triste durante muito tempo, foi um momento feio. A pintura serviu para me curar. Meu sobrinho já não está nessa forma (humana), mas passou a ser outras coisas. Passou a ser pintura, a ser recordação, canções que me coloco a escutar.

\section{Antes de "Universo Paralelo", você tinha outros tipos de desenhos, mais ligados à observação do cotidiano. O que aconteceu com $\mathrm{D}$ * foi uma linha divisória? Como aconteceu essa transição?}

AP - Eu trabalhava mirando as crianças, as outras pessoas. Era muita observação. Uma observação externa. E quando aconteceu tudo isso passou a ser uma observação para dentro. São duas formas de trabalhar. É como fazer uma paisagem, só que interna. Creio que esse seja o paralelo, uma observação interna para dentro. Fazer observações de mim mesmo. Mostrar um pouco mais quem sou eu, o que eu sinto. Nesse momento eu passei a ser o protagonista da obra e não uma terceira pessoa. Quando aconteceu isso (morte do sobrinho) houve um giro muito grande, um giro de imagem, um giro de muitas coisas. Você pode se autoflagelar por coisas que passaram ou transformar isso em algo positivo. Não sei. O corpinho de $\mathrm{D}^{*}$ foi enterrado em um parque, em um caixão. São formas de ver a vida, o mundo, as coisas que nos passam. Eu posso encarar isso como algo horrível que me passou, ou posso aprender com isso. Eu trato de aprender. Nem sempre posso aprender, não sou um "iluminado".

\section{Sobre a evolução do seu trabalho, há algum tempo você retratava mais máscaras e, agora, são plantas cobrindo os rostos. Por que isso?}

AP - As máscaras e as plantas acabam tendo o mesmo significado. O que mudou foi a representação. Até pouco tempo atrás eu estava pintando mais coisas internas, coisas que diziam respeito aos meus sentimentos. Agora estou saindo um pouco disso, na verdade as máscaras estão se fundindo com a natureza, uma comunhão. É como se você construísse um edifício e vão crescendo plantas ao redor dele, e ele acaba se tornando a própria natureza. Agora estou falando de uma essência mais pura, de onde eu venho, é muito mais espiritual. Não se trata mais de sofrimento e alegria, agora é outra questão. Não poderia estar falando de plantas sagradas se estou falando de D*, porque com D* tinha uma relação como tio, como filho, enfim, é uma relação construída com os anos, agora estou falando de outro ponto, talvez. Isso está variando. Mas é porque está variando a minha pessoa, não? Já não sofro, já não fico lidando com esse sentimento e chorando. Esse sentimento triste não está mais presente o tempo todo. Obviamente eu gostaria de ter D* comigo, e jogar com ele, abraçá-lo. Mas ok, está tudo em processo, e bom, são coisas que passam, me deu um empurrão para fazer uma obra, mas talvez eu pudesse ter trabalhado a partir disso. Não porque não poderia, pensando nos meus clientes, não. Na verdade, não penso nos meus clientes quando trabalho. Penso realmente no que se passa em mim.

\section{É possível dizer que seu trabalho é como se fosse um diário seu?}

AP - Sim, totalmente. Eu não escrevo, pinto diretamente. Há pessoas que vão ao psicólogo, talvez. Eu falo com meus amigos, ou com meu namorado, ou com o que se passa na tela. Não sei, creio na psicologia, mas não creio nos psicólogos. Me parece mais válido, por exemplo, através das plantas você fazer uma revisão interna, um autoconhecimento. Há muitas pessoas que podem ser ajudadas por um psicólogo, no meu caso já não sei se seria 
possível. Não poderia dedicar o tempo e o dinheiro que as pessoas dedicam a um psicólogo. E as plantas me proporcionam essas imagens e mais, que me proporcionam um efeito maravilhoso também. Passear por lugares que você nunca viu, é uma ferramenta fantástica.

\section{Como é o seu dia no atelier?}

AP - A primeira coisa que faço é um mate, e depois coloco uma música. Preparo tudo e me coloco a pintar, e aí o dia passa. Por vezes vou ao terraço e fico observando quem passa. Pinto por horas e sigo pintando. Talvez traga um amigo para trabalhar no atelier e... sigo pintando. Mas é um trabalho como qualquer outro. Alguns artistas são associados como hippies, mas eu não. Talvez um hippie moderno, não sei. O conceito que se tem de um hippie original é diferente do que se tem agora. Mas enfim, quando não estou trabalhando com um pincel na mão estou trabalhando na minha cabeça.

\section{Quais são os artistas que lhe inspiram?}

AP - Um artista que me inspirou muito foi Rousseau. Eu extraio coisas do trabalho dele para utilizar em minhas pinturas. Uma vez estive em Berlim, vi em um museu uma obra dele, e nunca entendi como vivendo em uma cidade da França pintava tantas paisagens do sudoeste asiático, e havia essa dualidade em sua obra. Além disso eu sabia que ele era aduaneiro, e também artista, tinha esse trabalho formal. E me parece que ele nunca saiu de sua cidade, e com sua cabeça e sem internet, fazia essas viagens e pintava todos esses lugares. E me fascinou essa sua cabeça e sua imaginação. É como se houvesse um paralelismo da minha vida com a dele, porque tenho esse trabalho formal (editar fotos e vídeos) e fazer minhas pinturas, são duas caras da mesma moeda, com a mesma pessoa. Há muitos outros artistas que entram e saem das minhas inspirações, como Goya, Magritte, claramente. Depois outros que me parecem charmosos tecnicamente, como Dalí. Mas a verdade é que a obra de Dalí não me encanta. É uma obra também que trata dos sonhos, do inconsciente paralelo, mas é muito técnico. Rousseau e Magritte já têm essa imagem muito mais crua, uma técnica mais crua, muito mais humana.

\section{Em qual gênero de arte seu trabalho mais se aproxima? Um realismo? Um surrealismo?}

AP - Acho que existem duas formas, conceitualmente e tecnicamente. Conceitualmente talvez é um realismo mágico, um realismo paralelo. E tecnicamente pode ser algo realista, porque é possível identificar claramente com a técnica, com a imagem, o que representa isso. São plantas, uma máscara de plantas, é uma pessoa, as cores são realistas. Mas a técnica é algo de quadro a quadro, me parece mais uma questão conceitual, um realismo mágico, um universo paralelo.

\section{Referências}

BACHELARD, Gaston. La poétique de la rêverie. 5. ed. Paris: P.U.F., 1971.

SALLES, Cecília Almeida. Crítica genética: fundamentos dos estudos genéticos sobre o processo de criação artística. São Paulo: EDUC (2008).

WEBER, Cristiane. Com amor, Alejandro: percursos emocionais, criativos e afetivos envolvidos na manifestação pictórica de um universo paralelo / Cristiane Weber-2019. 208 f.: il. Color.; $30 \mathrm{~cm}$. 